JOURNAL OF SECURITY AND SUSTAINABILITY ISSUES

ISSN 2029-7017 print/ISSN 2029-7025 online

2018 December Volume 8 Number 2

http://doi.org/10.9770/jssi.2018.8.2(1)

Scopus

\title{
MILITARY ACTIVITIES IN THE EXCLUSIVE ECONOMIC ZONE. A CONTENTIOUS ISSUE OF THE INTERNATIONAL LAW OF THE SEA
}

\author{
Tiziana Melchiorre ${ }^{1}$, Tomas Plèta ${ }^{2}$ \\ ${ }^{1,2}$ NATO Energy Security Centre of Excellence, Institution, Šilo g. 5A, LT-10322 Vilnius, Lithuania \\ E-mails: ${ }^{1}$ tizianamelchiorre@hotmail.com; tomas.pleta@enseccoe.org
}

Received 15 February 2018; accepted 11 December 2018; published 30 December 2018

\begin{abstract}
This article analyses military activities in the Exclusive Economic Zone (EEZ) from a legal point of view. It starts from the discussion of the principles of Mare Liberum and Mare Clausum, which are at the basis of the United Nations Convention of the Law of the Sea (UNCLOS). This latter is the main instrument regulating the relations among states at sea. The tension between the two principles reflects the tension between coastal State control and maritime State that dominates the whole discussion on which this article is written. The analysis is supported by a recent example, namely the NordBalt case that clearly shows both the uncertainty of the issue and the relevance of the topic in the relations between states.
\end{abstract}

Keywords: military activities, Exclusive Economic Zone, UNCLOS, NordBalt cable

Reference to this paper should be made as follows: Melchiorre, T.; Pleta, T. (2018). Military activities in the Exclusive Economic Zone. A contentious issue of the international law of the sea, Journal of Security and Sustainability Issues 8(2): 127-142. http://doi.org/10.9770/jssi.2018.8.2(1)

JEL Classifications: F01

Additional disciplines: law; political sciences

\section{Introduction}

This article provides an analysis of military activities in the Exclusive Economic Zone (EEZ), which has become a relevant issue in the relations among states over the last decades. Since 1982, when the United Nations Convention on the Law of the Sea (UNCLOS) was concluded and the EEZ concept was introduced, several contentious cases concerning military activities in the EEZ of another state have been discussed and debated. Scholars have accomplished several studies on the topic analysing the issue from a legal perspective on the basis of the related UNCLOS articles while often focusing on a specific case study. This latter often concerns the East Asia or the United States (US).

This article tries to enrich the debate on the topic. In order to do so, it starts with the analysis of the main principles that are at the basis of UNCLOS of 1982 and continues with the discussion of the Exclusive Economic Zone (EEZ) and of military activities in the EEZ. Additionally, the case of the NordBalt cable is used to give the reader a good example of how contentious the issue of military activities in the EEZ is while contributing to the field by focusing on the Baltic Sea region. This latter is defined as including Denmark, Estonia, Finland, Germany, Latvia, Lithuania, Poland, Russia, and Sweden. This case essentially consists in the Russian interference in the construction of the NordBalt cable through military activities in the EEZ. It well illustrates not only the uncertainty of some international law issues such as military activities in the EEZ but 
also the fact that they have become a hot topic for states especially during the last decades. The choice of this case lies on the fact that it is one of the most recent cases occurred as well as on the fact that it involves Russia whose aggressive behaviour in its neighbourhood in the last years is a big concern internationally.

Given this background, the main elements that this article takes into consideration are essentially three. The first one are the principles that are the foundations of UNCLOS and that are important in order to better understand the case study, namely Mare Liberum and Mare Clausum. The second element is the EEZ as defined by UNCLOS. The third element are military activities in the EEZ with a focus on the NordBalt cable as an example.

These elements correspond to the four sections in which this article is divided. The first one discusses UNCLOS with a focus on the contrast between the principles of Mare Liberum and Mare Clausum. The second section discusses the EEZ that is one of the main concepts of the international law of the sea and that is at the basis of the analysis. The third section focuses on military activities in the EEZ showing how uncertain they are in the international law. Finally, the fourth section provides a legal interpretation of the NordBalt case, which is a good example of the uncertainty of military activities in the EEZ.

\section{The United Nations Convention on the Law of the Sea of 1982: Mare Liberum versus Mare Clausum}

UNCLOS, which creates a comprehensive regime regulating the rights and the duties of states with respect to the world's seas, is the result of a long historical and political process begun in the seventeenth century. It was in fact in 1609 that a Dutch jurist, Hugo Grotius, published the first book on international law and the law of the sea under the title 'Mare Liberum' or 'The Free Sea' (Anand, 1983). Grotius 'was the first to proclaim the freedom of the seas by elaborate argument', which later became an unchallenged doctrine of international law, of which he is considered to be the father (Anand, 1983). The concept of the freedom of the seas together with the nations' control of the sea adjacent to their coasts was the foundation of the law of the sea for centuries (Bean, 2015). Therefore, the oceans were separated into 'territorial waters', which was a narrow band where coastal states possessed rights similar to the rights they exercised over their land territory, and 'high seas', which were a vast area where all states enjoyed the freedom to use those waters and natural resources (Ebbin, Hoel, Sydnes, 2005). However, it is worth noting that the 'Mare Liberum' concept has been challenged until nowadays by the emergence of another one in the same period, namely 'Mare Clausum', which was developed by English scholar John Selden in the seventeenth century. The issue at stake was whether the sea is international territory and all nations are free to use it or whether it can be claimed by individual states. The tension between these two concepts is still apparent in the present structure of the law of the sea (World Ocean Review, 2017).

While for centuries the law of the sea was essentially customary and international agreements involved a small number of states or covered a particular region, it was only in the second half of the twentieth century that the necessity of developing a treaty-based regime for ocean governance emerged. It was in fact in this period that the sea became increasingly important for coastal states as a source of natural resources such as oil and gas. Therefore, many of them tried to extend their national jurisdiction over large areas of the sea and the seabed (Bean, 2015). For this reason, immediately after the Second World War, the international community requested that the United Nations International Law Commission codified the existing laws relating to the oceans. (GRID Arendal, 2014). This latter prepared four conventions and an optional protocol that were adopted in 1958 by the First United Nations Conference on the Law of the Sea (UNCLOS I), which was attended by 86 states. However, the conventions failed to solve the fundamental issue of the breadth of the territorial sea while just stressing the need of solving the issue concerning the limits of coastal states jurisdiction over the continental shelf (GRID Arendal, 2014; Oxman, 1996). Additionally, the Conference did not succeed in ensuring the unity of the law of the sea as it did not keep the provisions in one instrument only. As Judge of the Tribunal of the Law of the Sea Tullio Treves puts it, "the adoption of four conventions and a protocol in lieu of one allencompassing convention may be seen, and was conceived, as a device to attract the acceptance by a broad number of States of at least some of the Conventions, in this way avoiding very radical reservations, or the decision by certain States not to accept an all-encompassing convention because of opposition to one or more 
of its main component parts" (Treves, 2017). At the same time, multilateralism was a fundamental point of the Convention. The effort to involve as many states as possible aimed at demonstrating that their basic interests could be accommodated through global multilateral negotiation on the basis of consensus. Also, it laid the foundation for a globally ratified Convention under which multilateral negotiation could be conducted as a basis for future development and refinement of the law of the sea (Oxman, 1996).

Nevertheless, UNCLOS I left fundamental issues unsolved, which were the question concerning the breadth of the territorial sea and the delimitation of a fisheries zone (Brilmayer, 2001; Anand, 1983). These issues were the main object of UNCLOS II held in Geneva in 1960 that, however, did not succeed in solving them. Additionally, differently from UNCLOS I, UNCLOS II did not even provide any Convention.

It was only in 1982 that the International Law of the Sea became a coherent body of provisions forming an integral package called 'Constitution for the Oceans' as a result of UNCLOS III. This conference was organized as a response to the request of Malta's permanent representative to the United Nations Arvid Pardo to the General Assembly to consider the formulation of an international treaty and the establishment of an international agency to regulate activities on the deep seabed by establishing it as the common heritage of mankind. Pardo's request stemmed from its concern that there was no well-defined legal framework that could ensure a fair exploitation of natural resources by all states. In fact, the high seas were subject to the laissez faire laissez passer attitude of Grotius' 'Mare Liberum' concept (Buttigieg, 2016). The Convention of Geneva on the Law of the Sea of 1958 was indeed an attempt to keep the high seas free for navigation and fair trading. It declared that the coastal states had the sovereign right to explore and exploit the natural resources of the continental shelf as long as these resources were to be found in depths of 200 metres and as long as the depth of the overlying waters allowed the exploitation of the natural resources of the seabed and subsoil of the submarine areas. Additionally, the Geneva Convention allowed a coastal state to divide its resources with another coastal state on the opposite side of the sea. This meant that technologically developed states would have exclusive rights to exploit natural resources as they had the capabilities to do so (Neves Coelho, 2013; Buttigieg, 2016). This concern was at the basis of the confrontation between the developed states seeking to maximize their benefits from the sea and the developing states aiming at changing the old international law of the sea in order to develop new equitable law for the exploitation of the seabed resources (Anand, 1978). The ideological differences between developed and developing states, which led to different interpretations of the common heritage of mankind principle, have never been overcome. Therefore, there has been no juridical consideration of the principle and, consequently, no legal requirements to define it (Guntrip, 2003).

UNCLOS III began in 1973 and lasted nine years until 1982. It was divided into three sessions. The first one was held in New York and was devoted to organizational issues and to the preparation of draft rules for procedures. The second and the third sessions, which were the most substantive sessions, were held in 1974 in Caracas where the draft texts were prepared and in 1975 in Geneva where the work of the three Main Committees formed during the sessions in Caracas consisted of the review of the draft texts. The Geneva session represents an advance over the Caracas session in two ways. Firstly, it confirmed the universal support for the 12 nautical mile territorial sea and of 200 nautical mile economic zone. Secondly, the Geneva session produced a single negotiating text while the Caracas drafts included alternative provisions. The Geneva text constituted a step forward towards the 'Constitution for the Oceans' or UNCLOS III that was approved in 1982 (Milic, 1976). It took some time for the final text to be accepted because most industrialized states rejected it at first as it contained several contentious provisions on deep sea mining. It was finally accepted when the provisions were changed in such a way that they were accepted by the developed states. It entered into force in 1994 (World Ocean Review, 2017) in accordance with its article 308. Today, "UNCLOS III is the globally recognized regime dealing with all matters relating to the law of the sea" (Division for Ocean Affairs and the Law of the Sea, 2017). There are currently 168 States Parties to the United Nations Convention on the Law of the Sea (International Tribunal for the Law of the Sea, 2017), which is constituted of 17 parts, 320 articles and 9 annexes.

Additionally, it is worth mentioning here that unlike most other treaties, a unique feature of UNCLOS III is that it contains mandatory provisions on the settlement of disputes, regulated in Part XV. In particular, article 
279 states that "States Parties shall settle any dispute between them concerning the interpretation or application of this Convention by peaceful means in accordance with Article 2, paragraph 3, of the Charter of the United Nations and, to this end, shall seek a solution by the means indicated in Article 33, paragraph 1, of the Charter" (United Nations, 1982). Additionally, in its Annex VI, UNCLOS established the International Tribunal for the Law of the Sea (ITLOS) 'to adjudicate disputes arising out of the interpretation and application of the Convention' (International Tribunal for the Law of the Sea, 2017). However, ITLOS is not the only judicial institution in charge of safeguarding compliance with UNCLOS. Indeed, according to art.287, "a State shall be free to choose, by means of a written declaration, one or more of the following means for the settlement of disputes concerning the interpretation or application of this Convention: a) the International Tribunal for the Law of the Sea (...); b) the International Court of Justice; c) an arbitral tribunal constituted in accordance with Annex VIII for one or more of the categories of disputes specified therein" (United Nations, 1982).

Therefore, although UNCLOS clearly regulates the duties and rights of states at sea, its provisions show the unresolved tension between the principles of Mare Liberum and Mare Clausum.

\section{The Exclusive Economic Zone}

The Exclusive Economic Zone (EEZ) is one of the major achievements of UNCLOS III. It was the result of the negotiations between the coastal states and the major maritime powers. In particular, the underlying purpose for creating the EEZ regime was to give coastal states increased rights over the living and non-living resources off their coasts in order to promote the development of economically weak countries (Milic, 1976). In this context, two elements can be considered as the driving forces behind the creation of EEZs. The first one is the desire of coastal states to control the fish harvest in adjacent waters as a result of the growth of fishing in the 1950s and in the 1960s. The second element is the heightened concern over control of offshore oil reserves due to the oil embargo and to the skyrocketing of prices as a consequence of the Arab-Israeli war in 1973 (United Nations, 1998). At the same time, the creation of the EEZ regime aimed at limiting the trend of national claims to broader territorial seas and at preserving as many high seas freedoms as possible (Beckman, Davenport, 2012; Roach, A., Smith, R., 1994).

Although the EEZ concept was legally defined in the UNCLOS of 1982 for the first time, the EEZs already existed in customary law. The first relevant assertion of exclusive jurisdiction over marine resources beyond the territorial sea was made by the United States of America (USA) in the Truman Proclamation of 1945 on the continental shelf. The Proclamation states that "having concern for the urgency of conserving and prudently utilizing its natural resources, the Government of the United States regards the natural resources of the subsoil and sea-bed of the continental shelf beneath the high seas but contiguous to the coasts of the United States as appertaining to the United States, subject to its jurisdiction and control" (Nandan, no date available). In the decades following the Second World War, several Latin American states and a few African states claimed to extend their territorial sea to 200 nautical miles essentially to obtain the exclusive right to fish and to regulate fishing in their area (Roach, Smith, 1994). The first international instrument to proclaim a 200-mile limit was the Santiago Declaration of 1952. It was signed by Chile, Ecuador and Peru and reflects the desire of those states to develop the resources of their coastal waters. It asserts that "owing to the geological and biological factors affecting the existence, conservation and development of the marine fauna and flora of the waters adjacent to the coasts of the declarant countries, the former extent of the territorial sea and contiguous zone is insufficient to permit of the conservation, development and use of those resources, to which the coastal countries are entitled". The three states proclaimed "as a principle of their international maritime policy that each of them possesses sole sovereignty and jurisdiction over the area of sea adjacent to the coast of its own country and extending not less than 200 nautical miles from the said coast". The Declaration also recognised the sole sovereignty and jurisdiction over the sea floor and subsoil and maintained the principle of innocent passage through the zone but not freedom of navigation. Later, in 1972, 16 African states met at a regional seminar on the Law of the Sea in Yaounde', in Cameroon. Recommendation I of the Conclusions, which were unanimously adopted, states that the "African states have equally the right to establish beyond the territorial sea, an economic zone over which they will have exclusive jurisdiction and national exploitation of the living resources of the sea and their 
conservation for the primary benefit of their people and their respective economies, and for the purpose of the prevention and control of pollution". The Conclusions also state that "sovereignty over all the resources of the high seas adjacent to their territorial sea within an economic zone to be established, and which will include at least the continental shelf" (Nandan, no date available).

UNCLOS III gave a legal basis to the EEZ concept. The EEZ was supported by those states that considered it as 'the pivotal feature in the law of the sea', while it was opposed by those states that believed that it could endanger freedom of navigation and that could become a source of disputes. Consequently, when defining the concept of the economic zone it was foreseen that "the rights of the coastal states should be exercised without interfering with other states' legitimate uses of this area with regard to freedoms of navigation, overflight, laying cables and pipelines, and scientific research" (Milic, 1976). The result of the negotiations over the EEZ was the Part V of UNCLOS from Article 55 to Article 75. Article 55 defines the EEZ as "an area beyond and adjacent to the territorial sea, subject to the specific legal regime established in this Part, under which the rights and jurisdiction of the coastal State and the rights and freedoms of other States are governed by the relevant provisions of this Convention" (United Nations, 1982). It is interesting to note that by stressing that the EEZ is an area adjacent to the territorial sea that is subject to the specific legal regime established by Part V, Articles 55 makes clear that the EEZ is not a part of the territorial sea and that it is a zone sui generis with a status of its own. (United Nations, 1982; Patuzi, 2015). Article 86 concerning the High Sea in Part VII also stresses this element by specifying that it "does not entail any abridgement of the freedoms enjoyed by all States in the exclusive economic zone" (United Nations, 1982).

The breadth of the EEZ is defined in Article 57 stating that "the exclusive economic zone shall not extend beyond 200 nautical miles from the baselines from which the breadth of the territorial sea is measured". Article 74 states that in case of states with opposite or adjacent coasts the delimitation of the EEZ shall be effected by agreement on the basis of international law. If the Parties can't reach any agreement, they shall resort to the procedures provided for in Part XV. Also, article 59 affirms that "in cases where this Convention does not attribute rights or jurisdiction to the coastal State or to other States within the exclusive economic zone, and a conflict arises between the interests of the coastal State and any other State or States, the conflict should be resolved on the basis of equity and in the light of all the relevant circumstances, taking into account the respective importance of the interests involved to the parties as well as to the international community as a whole" (United Nations, 1982). EEZs have brought $20 \%$ of the oceans under the national jurisdiction of coastal states (Ebbin, Hoel, Sydnes, 2005). The countries benefiting from the EEZ concept are in order of the zone of their zone the United States (US), Australia, Indonesia, New Zealand, Canada, and Russia (Patuzi, 2015).

The rights, the jurisdiction and the duties of coastal states are addressed in Article 56, which distinguishes sovereign rights from jurisdiction. The coastal states have sovereign rights "for the purpose of exploring and exploiting, conserving and managing the natural resources, whether living or non-living, of the waters superjacent to the seabed and of the seabed and its subsoil, and with regard to other activities for the economic exploitation and exploration of the zone, such as the production of energy from the water, currents and winds" (United Nations, 1982). Article 60 affirms that the coastal states have a jurisdiction with regard to: (a) the establishment and use of artificial islands; $b$ ) installations and structures for the purposes provided for in article 56 and other economic purposes; (c) installations and structures which may interfere with the exercise of the rights of the coastal State in the zone. Article 60 states that the coastal states must give due notice of the construction of such artificial islands, installations, and structures and they must maintain permanent means for giving warning of their presence. The coastal states are also obliged to remove any abandoned or disused installations and structures to ensure safety of navigation. In doing so, they must take into account any generally accepted international standards established in this regard by the competent international organization. Such removal shall also have due regard to fishing, the protection of the marine environment and the rights and duties of other States. The coastal states must give appropriate publicity to the depth, position and dimensions of any installations or structures not entirely removed. If necessary, the state can establish reasonable safety zones around such artificial islands, installations or structures where it should take the necessary measures to ensure safety of navigation and of such islands, installations and structures. The breadth of these zones must 
be determined by the coastal states on the basis of the international standards. These zones shall not exceed a distance of 500 metres around the islands, the installations and the structures, which shall be measured from each point of their outer edge, except as authorized by generally accepted international standards or as recommended by the competent international organization. All ships must respect these safety zones and shall comply with generally accepted international standards regarding navigation in the vicinity of artificial islands, installations, structures and safety zones. However, UNCLOS III states that artificial islands, installations and structures and the safety zones around them may not be established where interference may be caused to the use of recognized sea lanes essential to international navigation. Additionally, artificial islands, installations and structures do not possess the status of islands, do not have a territorial sea of their own, and their presence does not affect the delimitation of the territorial sea, the exclusive economic zone or the continental shelf. (United Nations, 1982).

Articles 61 and 62 regulate the conservation and the utilisation of living resources respectively. 'Living resources' refers to non-sedentary species found in the water column superjacent to the seabed, including marine mammals, highly migratory species, shared and straddling stocks, anadromous and catadromous species, and sedentary species of the seabed and its subsoil, as specified by articles 61-68 (United Nations,, 1982). However, Article 68 clarifies that Part V does not apply to sedentary species although they should be treated as having the same status as the non-sedentary ones for the purpose of conservation and management in practice. According to Article 61, "the coastal State shall determine the allowable catch of the living resources in its exclusive economic zone". They "shall ensure through proper conservation and management measures that the maintenance of the living resources in their exclusive economic zone is not endangered by over-exploitation" (United Nations, 1982). To this end, the coastal states shall cooperate as appropriate with competent international organisations, whether subregional, regional or global, by taking into consideration the best scientific evidence. According to article 62, "the coastal State shall promote the objective of optimum utilization of the living resources in the exclusive economic zone" and "shall determine its capacity to harvest the living resources of the exclusive economic zone (...). Where the coastal State does not have the capacity to harvest the entire allowable catch, it shall, through agreements or other arrangements and pursuant to the terms, conditions, laws and regulations referred to in paragraph 4 [stating that they have to comply with the conservation measures and with the other terms and conditions established in the laws and regulations of the coastal State. These laws and regulations shall be consistent with this Convention], give other States access to the surplus of the allowable catch (...) especially in relation to the developing States". Additionally, article 69 states that "land-locked States shall have the right to participate, on an equitable basis, in the exploitation of an appropriate part of the surplus of the living resources of the exclusive economic zones of coastal States of the same subregion or region, taking into account the relevant economic and geographical circumstances of all the States concerned and in conformity with the provisions of this article and of articles 61 and 62". The coastal states concerned shall establish the terms and modalities of such participation through bilateral, subregional or regional agreements. Additionally, "the coastal State and other States concerned shall cooperate in the establishment of equitable arrangements on a bilateral, subregional or regional basis to allow for participation of developing land-locked States of the same subregion or region in the exploitation of the living resources of the exclusive economic zones of coastal States of the subregion or region". This should happen in case the harvesting capacity of a coastal State approaches a point which would enable it to harvest the entire allowable catch of the living resources in its exclusive economic zone. It is also worth noting that Article 69 makes an explicit reference to developed states asserting that they "shall be entitled to participate in the exploitation of living resources only in the exclusive economic zones of developed coastal States of the same subregion or region having regard to the extent to which the coastal State, in giving access to other States to the living resources of its exclusive economic zone, has taken into account the need to minimize detrimental effects on fishing communities and economic dislocation in States whose nationals have habitually fished in the zone".

As for the rights and duties of other states in the EEZ, article 58 provides that all states enjoy "the freedoms referred to in article 87 of navigation and overflight and of the laying of submarine cables and pipelines, and other internationally lawful uses of the sea related to these freedoms, such as those associated with the operation of ships, aircraft and submarine cables and pipelines, and compatible with the other provisions of this 
Convention" (United Nations, 1982). Article 58 also provides that other states have two duties when exercising their rights in the EEZ. Firstly, they shall have 'due regard' to the rights and duties of the coastal state. They don't need to have 'due regard' to the interests of the coastal states, but only to their rights and duties, which are limited to rights to the natural resources and other economic activities. Therefore, there is no obligation for other states to give due regard to the security interests of the coastal state in the EEZ (Beckman \& Davenport, 2012). Secondly, other states must comply with the laws and the regulations adopted by the coastal state, but only such laws that are in accordance with the laws and regulations adopted by the coastal state in accordance with the provisions of the Convention and other rules of the international law, and only if they are compatible with the other provisions of the Convention (United Nations, 1982). Additionally, article 58 stipulates that articles 88 to 115 and other pertinent rules of international law apply to the EEZ in so far as they are not incompatible with Part V of UNCLOS on the EEZ. This implies that the high seas provisions on jurisdiction apply in the EEZ (Beckman \& Davenport, 2012). In particular, it is worth mentioning articles 92 and 95. Article 92 on the exclusive jurisdiction of the flag state states that ships can sail under one flag only and, save in exceptional cases expressly provided for in international treaties or in this Convention, shall be subject to its exclusive jurisdiction on the high seas. A ship may not change its flag during a voyage or while in a port of call, save in the case of a real transfer of ownership or change of registry". The same article also states that a ship sailing under the flags of two or more states can't claim any of the nationalities in question in respect to any other state, and may be assimilated to a ship without nationality (United Nations, 1982). Article 95 on the immunity of warships on the high seas states that "warships on the high seas have complete immunity from the jurisdiction of any state other than the flag state" (United Nations, 1982). This means that the rules on jurisdiction in the EEZ are the same as those on jurisdiction on the high seas, except for the express provisions in UNCLOS giving coastal states jurisdiction over specific matters in the EEZ (Beckman \& Davenport, 2012).

Given this background, it is evident that the essence of the EEZ is the balance between coastal states rights and the rights of the other states. However, this balance is being challenged by the tendency of the coastal states to adopt their national legislation enhancing their competences and jurisdiction and restricting the freedoms recognized in the EEZ of "navigation and overflight and of the laying of submarine cables and pipelines and other internationally lawful uses of the sea related to these freedoms" as stated in article 58 (United Nations, 1982). This has been defined as 'creeping jurisdiction' or the 'territorialisation' of the EEZ. Nevertheless, this UNCLOS III has put in place some mechanisms to prevent this possibility from occurring. This is evident in the cases of navigational freedoms in the EEZ and of the freedom to lay submarine cables and pipelines (Beckman $\&$ Davenport, 2012). In the case of navigational freedoms, two areas well illustrate the issue. The first one is the protection of the marine environment from ship-source pollution. According to article 211(5), "Coastal States (...) may in respect of their exclusive economic zones adopt laws and regulations for the prevention, reduction and control of pollution from vessels conforming to and giving effect to generally accepted international rules and standards established through the competent international organization [which in this case is the International Maritime Organisation] or general diplomatic conference" (United Nations, 1982). This means that coastal states are limited to adopting laws and regulations which conform to and give effect to the International Convention for the Prevention of Pollution From Ships 1973, as modified by the Protocol of 1978 (MARPOL 73/78) and its annexes. Another relevant feature is article 211(6) that allows coastal states, after appropriate consultations with the competent international organization, to adopt stricter laws and regulations in special areas of their EEZ recognized technical reasons in relation to its oceanographical and ecological conditions, as well as its utilization or the protection of its resources and the particular character of its traffic" (United Nations, 1982). This article allows the International Maritime Organisation (IMO) to designate an area in the EEZ as a particularly Sensitive Sea Area (PSSAs).

The second area of the navigational freedoms is maritime security. This issue is very much related to the enforcement of UNCLOS against crimes at sea. The general rule is that the flag State has exclusive jurisdiction over vessels in the EEZ, with some limited exceptions. For instance, article 105 stipulates that all states have the power to arrest and prosecute vessels suspected of engaging in piracy. Similarly, article 110 affirms that all states have the right to board vessels if they have reasonable grounds for suspecting that the ship is engaged in piracy, the slave trade, unauthorized broadcasting or that the ship does not have a nationality (Beckman \& Davenport, 2012). 
In the case of freedom to lay submarine cables and pipelines, the EEZ regime incorporates the high seas freedom referred to in the article 87 mentioned above. In this context, two elements must be considered. The first one concerns the repair of cables. It is not explicitly mentioned in UNCLOS, but it should be considered "other internationally lawful uses of the sea" related to the freedom to lay cables including those associated with the operation of submarine cables (Beckman \& Davenport, 2012). The second element concerns the fact that the continental regime in Part VI governs the same geographical area of seabed as the EEZ regime. In particular, article 79 relating to submarine cables and pipelines on the continental shelf states that all states are entitled to lay submarine cables and pipelines on the seabed in accordance with the provisions of this article. It is interesting to note that although UNCLOS deals with cables and pipelines in the same article, it makes clear distinction between the rights of coastal states over pipelines and over submarine cables. With regard to cables, article 79 affirms that the coastal state can only subject the laying or maintenance of cables to 'reasonable measures' for the exploration of the continental shelf and for the exploitation of its natural resources. With regard to pipelines, in addition to the measures envisaged for cables, article 79 also stipulates that costal states shall take 'reasonable measures' for the prevention, reduction and control of pollution from pipelines. Additionally, "the delineation of the course for the laying of such pipelines on the continental shelf is subject to the consent of the coastal state". The difference between cables and pipelines is attributable to the fact that pipelines can carry noxious substances while cables are relatively benign (Beckman \& Davenport, 2012; United Nations, 1982).

Furthermore, it is necessary to stress that the EEZ can coincide with the Continental Shelf, as briefly mentioned in the previous paragraph. This latter is defined in Part VI of UNCLOS III. Article 76 defines it as comprising "the seabed and subsoil of the submarine areas that extend beyond its territorial sea throughout the natural prolongation of its land territory to the outer edge of the continental margin, or to a distance of 200 nautical miles from the baselines from which the breadth of the territorial sea is measured where the outer edge of the continental margin does not extend up to that distance" (United Nations, 1982). However, the EEZ and the Continental Shelf are two distinct maritime zones that differ in some important respects. Firstly, the Continental Shelf includes only the seabed and the subsoil whereas the EEZ also includes the water column. Secondly, while the maximum extent of the EEZ is 200 nautical miles, the continental shelf may extend beyond 200 nautical miles from the coastline, depending on the depth, shape, and geophysical characteristics of the seabed and subsea floor. Therefore, the Continental Shelf is not an extension of the EEZ. Thirdly, some of the sovereign rights that a coastal State may exercise in the EEZ, especially rights to the resources of the water column (e.g., pelagic fisheries), do not apply to the Continental Shelf (US Department of State, 2017).

Furthermore, UNCLOS also established a comprehensive dispute settlement framework in Part XV also containing specific provisions concerning the EEZ. In particular, article 297(1) provides that the disputes concerning the interpretation and the application of UNCLOS in relation to the exercise by a coastal state of its sovereign rights or jurisdiction provided for in UNCLOS shall be subject to the procedures provided in section 2 in two cases. Firstly, when it is alleged that the coastal state has acted in contravention of the provisions of the Convention with regard to the freedoms and rights of navigation, overflight or the laying of submarine cables and pipelines, or in regard to other internationally lawful uses of the sea as set out in article 58. Secondly, when it is alleged that another state, when exercising its rights under article 58 has acted in contravention of the Convention or in contravention of laws and regulations adopted by a coastal state in conformity with the Contravention (United Nations, 1982; Beckman \& Davenport, 2012).

Therefore, in a juridical sense, the EEZ is brackish, murky and treacherous water; it is a "band of turbulent ocean separating the territorial sea from the high seas in which competing desires for control and use meet, mix and merge. The EEZ is a zone of tension between coastal State control and maritime State use of the sea. The battle for control defines the exclusive economic zone. In the battle for control, it is a demilitarized zone, where neither coastal State nor maritime State rights prevail, yet both, in varying degrees, exist" (Galdorisi, Kaufman, 2001). In short, the EEZ is an issue that the international law of the sea should regulate better in order to eliminate all possible ambiguities. This should be done in order to precisely define the rights of the maritime states on the one hand and of the coastal states on the other one. 


\section{Military activities in the Exclusive Economic Zone}

Military activities in the EEZ is one of the areas least addressed in UNCLOS as well as in prior customary international law although this latter historically considered military manoeuvres 'a lawful use of the high seas associated with the operation of warships exercising freedom of navigation' (Galdorisi, Kaufman, 2001). Before UNCLOS III, they were not an issue as the EEZ was not a fully developed regime. After UNCLOS III, military activities were not an issue because other activities in other regimes were considered more important at that time. Today, military activities in the EEZ are a hot topic on the international agenda of states because they are becoming increasingly frequent for a number of reasons such as the rise in the size and quality of the navies of many nations, the technological advances that allow navies to exploit oceanic areas, the tremendous increase in world trade and the accelerating pace of globalisation. At the same time, the contention over the scope of the rights to military activities has also increased. A small number of countries (e.g. India, Malaysia, Brazil and Iran) interpret UNCLOS to prohibit naval activities and manoeuvres in the EEZ without their prior permission, while some others (e.g. Thailand, Italy, Germany, the Netherlands, the United Kingdom, and the United States) perceive this provision as one permitting naval operations in the EEZ as an activity 'associated with the operation of ships' and more generally as protected within the scope of the freedom of navigation (Galdorisi, Kaufman, 2001; Geng, 2012). In general terms, it is possible to affirm that most nations agree with the position advocated by the maritime states that "military operations, exercises and activities have always been regarded as internationally lawful uses of the sea. The right to conduct such activities will continue to be enjoyed by all states in the exclusive economic zone" (Pedrozo, 2014).

This divergence in the perspective concerning the legality of foreign military activities in the EEZ is partly due to the varying interpretations of article 58 allowing maritime states to engage in "other internationally lawful uses of the sea related to these freedoms, such as those associated with the operation of ships, aircraft and submarine cables and pipelines, and compatible with other provision of the Convention". The expression 'other internationally lawful uses of the sea' refers to the fact that states can 'use' the sea without coastal state notice or consent and include a broad range of military activities such as conventional and ballistic missile testing, belligerent rights in naval warfare (e.g., right of visit and search), strategic arms control verification, maritime security operations (e.g., counter-terrorism and counter-proliferation), and sea control.

In this context, some states have exercised their right to make declarations on military activities under article 310, which however stresses that "such declarations or statements do not purport to exclude or to modify the legal effect of the provisions of this Convention in their application to the State" (United Nations, 1982; Geng, 2012). For instance, Brazil, Bangladesh, Cape Verde, Malaysia, India, and Pakistan have clearly expressed in their statements that they require consent before a foreign ship may conduct military activities in their EEZ. By contrast, states like Italy, Germany, the Netherlands, and the United Kingdom have protested against this interpretation stating that they are unduly restrictive on navigational freedoms that are the foundation for military activities at sea and as inconsistent with article 310 and UNCLOS (Geng, 2012). Nevertheless, although the language of UNCLOS is ambiguous, some evidence that the Convention did not intend to broadly exclude peacetime military operations in the EEZ does exist. In 1949, in fact, the Corfu Channel decision of the International Court of Justice (ICJ) refers to the freedom of navigation of warships in peacetime as a 'general and well-recognized principle'. The findings of the ICJ were influential in the development of the law of the sea in the UNCLOS conference as it is reflected in the deliberations at UNCLOS I and III and in both the Geneva Conventions and UNCLOS. Nevertheless, the decision of the Court did not specify the scope of the rights included in the freedom of navigation of warships (Geng, 2012).

While UNCLOS does not broadly exclude peacetime military operations, it does place some restraints on military activities at sea, although they do not apply to the EEZ. These restraints, which refer to territorial seas, archipelagic waters and to the Archipelagic Sea Lanes Passage (ASLP), are not found in Part V dedicated to the EEZ and therefore do not apply to warships, military aircraft and other sovereign immune ships and aircraft operating in or over the EEZ (Pedrozo, 2014). 
UNCLOS also makes clear that coastal states do not have competence to regulate military activities in the airspace above the EEZ especially when those activities do not have an impact on the water column or seabed of the EEZ. According to articles 2 and 49, the airspace above the territorial sea and archipelagic waters is national airspace, subject to coastal/archipelagic state sovereignty. The airspace above the EEZ is considered international airspace and, like the high sea, is not subject to coastal state sovereignty (Pedrozo, 2014).

Additionally, according to article 301, states "shall refrain from any threat or use of force against the territorial integrity or political independence of any State" (UNCLOS, 1982). UNCLOS makes a clear distinction between 'threat or use of force' and military-related activities. Indeed, article 19 prohibits states in innocent passage from engaging in "any threat or use of force against the sovereignty, territorial integrity or political independence of the coastal State, or in any other manner in violation of the principles of international law embodied in the Charter of the United Nations" (United Nations, 2017). The other subparagraphs restrict other military activities in the territorial sea

It is also interesting to note that article 301 repeats the language of article 2(4) of the UN Charter, which states that "all Members shall refrain in their international relations from the threat or use of force against the territorial integrity or political independence of any state, or in any other manner inconsistent with the Purposes of the United Nations" (United Nations, 1945). In fact, the determination of whether an activity is 'peaceful' is made under this article. Most commentators that have studied the issue agree that "based on various provisions of the Convention ... it is logical ... to interpret the peaceful...purposes clauses as prohibiting only those activities which are not consistent with the UN Charter. It may be concluded accordingly that the peaceful purposes ... clauses in Articles 88 and 301 do not prohibit all military activities on the high seas and in EEZs, but only those that threaten or use force in a manner inconsistent with the UN Charter" (Here it is necessary to specify that Article 88 states that "the high seas shall be reserved for peaceful purposes". United Nations, 1982).

As Captain Pedrozo points out, accepting that all military activities are by nature inconsistent with 'peaceful purposes' would mean that states could not operate military vessels or aircraft both in the EEZ and in the High Seas. However, this is in contrast with the decisions of the UN Security Council indicating that "military activities consistent with the principles of international law embodied in [Article 2(4) and Article 51 of] the Charter of the United Nations . . a are not prohibited by the Convention on the Law of the Sea". The Security Council has also determined that peacetime intelligence collection is not considered a "threat or use of force against the sovereignty, territorial integrity or political independence of the coastal state...in violation of the Charter of the United Nations" (Pedrozo, 2014). In this context, it is interesting to note that the "peaceful purposes' are not defined in UNCLOS. Peace means "no war and armed conflicts. Military activities should not be seen as war-like". Military manoeuvres and exercises have long been considered acceptable in the high seas as the military are seen as the vanguard of peace (Meng Soon, 2016).

Furthermore, UNCLOS makes it clear that also other international laws must be considered for legitimate uses in EEZs. Article 58 concerning rights and duties of other states in the EEZ states indeed that "articles 88 to 115 and other pertinent rules of international law apply to the exclusive economic zone in so far as they are not incompatible with this Part" and that "in exercising their rights and performing their duties under this Convention in the exclusive economic zone, States shall have due regard to the rights and duties of the coastal State and shall comply with the laws and regulations adopted by the coastal State in accordance with the provisions of this Convention and other rules of international law in so far as they are not incompatible with this Part" (UNCLOS, 1982). Indeed, UNCLOS is not the only international maritime law. An example is the San Remo Manual on the Law of Armed Conflicts at Sea that laid down the rules for combat. It rejects the interpretation that all military activities are inconsistent with the 'peaceful purposes' provisions of the Convention. It also provides that armed conflicts at sea can take place not only on the high seas but also in the EEZ of a neutral state. The only limitation that the Manual imposes is that belligerents must "have due regard for the [resource] rights and duties of the coastal state" in the EEZ (Pedrozo, 2014). Additionally, as Maj Meng Soon correctly argues, if 'peaceful purposes' had meant no military activities, the US and the Soviet Union would have not agreed upon UNCLOS as it was negotiated during the Cold War (Meng Soon, 2016). Other 
multilateral instruments recognizing that military activities at sea are the International Maritime Organisation (IMO)/International Hydrographic Organisation (IHO) World-wide Navigational Warning Service and the Chicago Convention. The former recognizes that military activities at sea like naval exercises and missile firings are lawful uses of the sea. The latter acknowledges in its Annex 15 the legitimacy of military activities in international airspace "by providing that military exercises that pose hazards to civil aviation are appropriate subjects for notices to airmen" (Pedrozo, 2014).

\section{The NordBalt cable case}

The NordBalt cable is an HVDC 700 MW subsea interconnection between Sweden and Lithuania. It is a joint project of Svenska Kraftnät and LitGrid (and co-financed by the EU) that was handed over to customers in 2016. It connects Klaipeda in Lithuania to Nybro in Sweden with a cable $400 \mathrm{~km}$ long (of which almost $350 \mathrm{~km}$ are under water). It incorporates special features such as active AC voltage support providing greater network stability and black-start capability providing faster grid restoration after a blackout. NordBalt has increased the trading capacity between the Baltic States and the Nordic electricity markets. It also helps to strengthen the security of the power supply in the three Baltic States (Estonia, Latvia and Lithuania) and in southern Sweden, and integrates an emerging joint Baltic electricity market with the Nordic and European markets (ABB, 2018). NordBalt contributes to make the three Baltic States less dependent on Russian-supplied electricity (RWH Advisory Group, 2015).

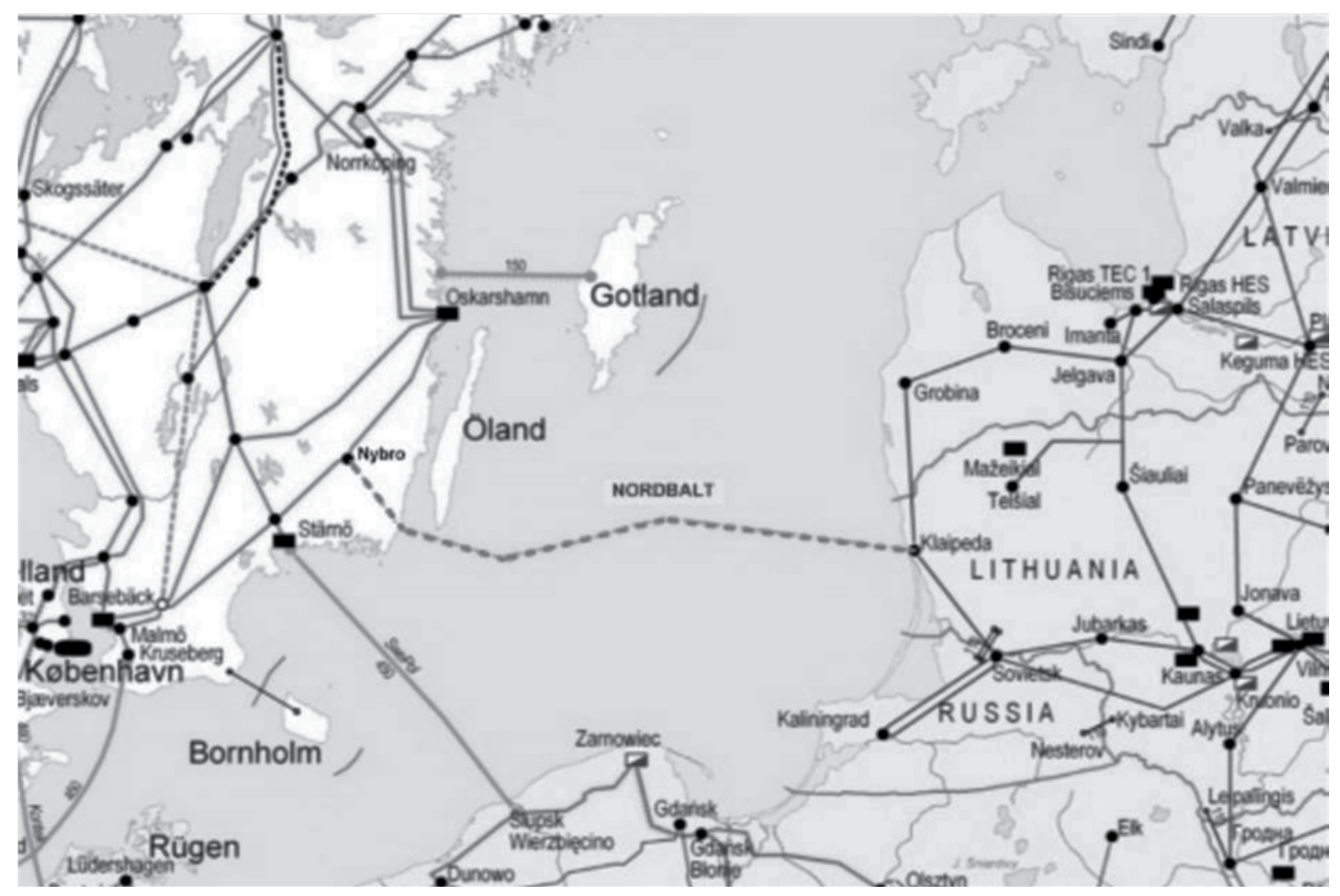

Figure 1. NordBalt cable

Source: Euractiv

https://www.euractiv.com/section/global-europe/news/russia-accused-of-disrupting-new-energy-link-between-sweden-and-lithuania/

Russia has always used its energy leverage on the three Baltic States in order to keep them dependent on its energy supplies. Energy is a powerful geopolitical instrument used by Russia in its foreign policy strategy in order to exert its economic and political power on its neighbours. This is one of the reasons why Russia criticizes Lithuania's efforts to disconnect from the BRELL (Belarus-Russia-Estonia-Latvia-Lithuania) 
electricity network managed from Moscow in order to connect (via Poland) to the continental European electricity transmission system. Lithuanian network synchronization with Europe would block the transmission grids between Belarus and Russia, which cross the Baltic States. Additionally, the electricity produced by the Russian-Belarus Ostrovets nuclear power plant (that is being constructed approximately $18 \mathrm{~km}$ away from Ostrovets, Grodno Oblast, Belarus), which is considered unsafe by many experts, could not enter the Baltic and European electricity market. Belarus and Russia are building the Ostrovets nuclear plant with the goal of selling power to Europe by using Lithuanian (and Baltic) infrastructure (Bankauskaite, 2018). This serves the Russian geopolitical and economic aim of exerting its energy leverage on the EU.

These reasons are also at the basis of the Russian interference with the construction of NordBalt in 2015. On April 30, 2015, Lithuania alleged that Russian warships illegally ordered a Swedish ship that was laying the NordBalt power cable to change course. Similar interventions were made by Russian naval vessels on March 29, April 10 and April 24. Russia argued that the reason of its order was that the area in which its ship was operating, which was part of the Lithuanian EEZ, had been selected for military exercises. Here it is necessary to stress that the information available for the analysis do not specify the breadth of the safety zone around the laying of the cable that Lithuania had determined according to article 60. In spite of this, it is possible to state with certainty that Russia disrupted the laying of NordBalt several times. This is the point of departure of the following discussion.As a consequence of the Russian behaviour, the Lithuanian Foreign Ministry demanded that Russia ceased "interfering with international shipping and legitimate economic activities", which was a violation of UNCLOS (RWR Advisory Group, 2015). Sweden supported Lithuania in its request through diplomatic protests (Radio Sweden, 2015) stressing that Russian interference in the construction of NordBalt was a "growing pattern" of Russian provocations (Braw, 2015). The Lithuanian Foreign Ministry complained that the "Russian authorities have never asked Lithuanian institutions or received any prior authorization for such activities in the exclusive economic zone of Lithuania" (Euractiv, 2015). However, as explained above, the expression 'other internationally lawful uses of the sea' contained in article 58 refers to the fact that states can 'use' the sea without coastal state notice or consent and include a broad range of military activities such as conventional and ballistic missile testing, belligerent rights in naval warfare (e.g., right of visit and search), strategic arms control verification, maritime security operations (e.g., counter-terrorism and counter-proliferation), and sea control. At the same time, article 310 on declarations and statements is interpreted in different ways by states, as discussed in the previous section. Some states require consent before a foreign ship may conduct military activities in their EEZ, some others consider consent unduly restrictive on navigational freedoms that are the foundation for military activities at sea are unduly restrictive on navigational freedoms that are the foundation for military activities at sea. In the case of NordBalt, it is very probable that Lithuania interpreted article 310 in the sense that Russia should have demanded consent before conducting military activities in its EEZ.

Nevertheless, in spite of the fact that Russia may have legally conducted military activities in the Lithuanian EEZ, it has infringed article 58. Indeed, the fact that the Russian navy has disrupted the construction of NordBalt means that it has not had 'due regard' to the right of Lithuania to deal with economic activities, which concern the lay of a cable in this specific case. Additionally, like article 56, article 58 stipulate that coastal and maritime states shall mutually respect each other's rights and duties in the EEZ. These articles are meant to balance the interests of various states in the EEZ. Nevertheless, 'due regard' is not defined in the Convention and is open to interpretation (Geng, 2012). By disrupting the construction of NordBalt, Russia has not respected Lithuanian rights. As Foreign Minister Linas Linkevicius argued, Russia's navy has the right to conduct exercises in the Baltic Sea, but it should "make sure that its military vessels don't create obstacles for the commercial vessels" in Lithuania's exclusive economic zone (Braw, 2015). Consequently, Russia has not respected Lithuania's freedom to lay submarine cables and pipelines, which should be considered part of the "other internationally lawful uses of the sea" defined in article 58. This is therefore strictly related to the Mare Liberum principle concerning the 'freedom of the seas'. Moreover, Russia has infringed this principle also for another important reason, namely the fact that it ordered a Swedish ship that was laying the NordBalt power cable to change course. Additionally, according to the same reasoning. It is possible to affirm that Russia has also infringed the San Remo Manual on the Law of Armed Conflicts at Sea also imposing that belligerents 'have due regard for the [resource] rights and duties of the coastal state' in the EEZ. 
Furthermore, another consideration concerns articles 88 and 301 pertaining to 'peaceful purposes'. The main principle here is that states shall use the high seas (and therefore the EEZ) only for peaceful aims and shall not threat or use the force against the territorial integrity or political independence of any state (article 301). The information available on the NordBalt case show that Russia has not infringed these two articles because nothing in its behaviour leads to think that it aimed at attacking Lithuania and/or Sweden. Additionally, as stated above, not all military activities are inconsistent with the 'peaceful purposes' provisions of the Convention, as the San Remo Manual on the Law of Armed Conflicts at Sea stipulates. In the NordBalt case, there are no reasons to affirm that Russian military activities were not peaceful.

Therefore, the NordBalt case well illustrate how complex the issue of military activities in the EEZ is. In spite of the fact that some information on the case are missing, facts show that Russia has infringed UNCLOS and the Mare Liberum principle that is its foundation.

\section{Conclusions}

Military activities in the EEZ are a complex and contentious issue in the field of the international law of the sea. UNCLOS, which provides the most comprehensive regime regulating states' rights and duties with respect to the world's seas, regulates military activities very poorly. The reason is that military activities in the EEZ have become a relevant topics for states only during the last decades. Additionally, UNCLOS contains some restraints on military activities only referring to territorial seas, archipelagic waters and to the ASLP but not to the EEZ. This latter still remains a zone of tension between coastal State control and maritime State use of the sea.

The NordBalt cable case has demonstrated that this tension is evident in two ways. First, article 58 on the 'lawful uses of the sea' is a clear example of the fact that this tension is reflected in the contrast between the Mare Liberum principle and the Mare Clausum one. Second, states differently interpret article 310 on declarations and statements as shown by the NordBalt cable case. While coastal states like Lithuania interpret article 310 in such a way that it requires consent for military activities, maritime states like Russia do not. Additionally, the analysis shows that while Russia (a maritime state) supports the Mare Liberum principle, Lithuania (a coastal state) and Sweden support the Mare Clausum one. Furthermore, the NordBalt case is a good example of the uncertainty of the military activities issue as well as of the relevance that military activities in the EEZ nowadays have for states in order to reach their foreign policy goals.

Consequently, military activities in the EEZ need to be properly addressed by the international law especially since they have recently become a hot topic on the international agenda of states. As several contentious cases have occurred all around the globe, military activities in the EEZ have become a sensitive issues for states. These latter could agree to regulate military activities in the EEZ more precisely and deeply through international laws that should be contained in a legal code separately from UNCLOS while using this latter as the foundation for it. A detailed and comprehensive code could reduce the ambiguities that could lead to tensions among states.

\section{References}

ABB. (2018). NordBalt. Retrieved from http://new.abb.com/systems/hvdc/references/nordbalt

Anand, R.P. (1983). Origin and development of the Law of the Sea. Publications on Ocean development. Volume 7. The Hague/Boston/ London. Martinus Nijhoff Publishers

Anand, R.P. (1978). Law of the Sea. Caracas and Beyond. Radiant Publishers. Kalkaji

Ayebeng, K. (2005). Theory in Search of Practice: The Right of Innocent Passage in the Territorial Sea. Cornell Law School Graduate Student Papers. Paper 9

Bankauskaite, D. (2018). Kremlin tests Baltic electric solidarity. CEPA. Retrieved from http://infowar.cepa.org/Briefs/Lt/KremlinTests-Baltic-Solidarity

Bean, B. (2015). Law of the Sea. E-RG Electronic resource Guide. American Society of International Law 
Beckman, R., Davenport, T. (2012). The EEZ Regime: Reflections after 30 Years. Securing the Ocean for the Next Generation. LOSI Conference Papers. University of California. Berkeley

Braw, E. (2015). Balts Say Russian Navy Bullying Undersea Cable Crews. Radio Free Europe Radio Liberty. Retrieved from https:// www.rferl.org/a/russia-bullying-undersea-baltic-cable/26996165.html

Brilmayer, L. (2001). Land and Sea: Two Sovereignty Regimes in Search of a Common Denominator. Faculty Scholarship Series. Yale Law School Faculty Scholarship. Yale. Paper 2523

Buttigieg, J. (2016). Arvid Pardo-a diplomat with a mission. Symposia Melitensia. Msida. Number 12

Cambridge Dictionary. (2017). Water Column. Retrieved from http://dictionary.cambridge.org/dictionary/english/water-column

Cohen, S. B. (2003). Geopolitics of the World System. Boston: Rowman \& Littlefield Publishers

Division for Ocean Affairs and the Law of the Sea. (2017). United Nations Convention on the Law of the Sea of 10 December 1982. Overview and full text. Retrieved from http://www.un.org/depts/los/convention_agreements/convention_overview_convention.htm

Dunlap, W. (1996). Transit Passage in the Russian Arctic Straits. Maritime Briefing. Vol.1 n.7. University of Durham. Durham

Ebbin, S., Hoel, A.H., Sydnes, A. (2005). A Sea Change: The Exclusive Economic Zone and Governance Institutions for Living Marine Resources. The Netherlands. Springer

Euractiv. (2015). Russia accused of disrupting new energy link between Sweden and Lithuania. Retrieved from https://www.euractiv. com/section/global-europe/news/russia-accused-of-disrupting-new-energy-link-between-sweden-and-lithuania/

Galdorisi, G., Kaufman, A. (2001). Military Activities in the Exclusive Economic Zone: Preventing Uncertainty and Defusing Conflict. CWSL Scholarly Commons

Geng, J. (2012). The Legality of Foreign Military Activities in the Exclusive Economic Zone under UNCLOS. Igitur. Utrecht Publishing \& Archiving Services. Utrecht

GRID Arendal. (2014). Background to UNCLOS. Retrieved from http://www.continentalshelf.org/about/1143.aspx

Guntrip, E. (2003). The Common Heritage of Mankind: an Adequate Regime for Managing the Deep Seabed. Melbourne Journal of International Law, 4(2) Melbourne

International Maritime Organization. (2017). International Convention for the Prevention of Pollution from Ships (MARPOL). Retrieved from http://www.imo.org/en/about/conventions/listofconventions/pages/international-convention-for-the-prevention-ofpollution-from-ships-(marpol).aspx

Koh, T. (1983). The Third United Nations Conference on the Law of the Sea: What Was Accomplished?. Law and Contemporary Problems, 46(2). Duke University School of Law. Durham

International Tribunal for the Law of the Sea. (2017). The Tribunal. Retrieved from https://www.itlos.org/en/the-tribunal/

Jia, B. (2014). The Principle of the Domination of the Land over the Sea: A Historical Perspective on the Adaptability of the Law of the Sea to New Challenges. German Yearbook of International Law. Issue 57

Milic, M. (1976). The United Nations Conference on the Law of the Sea. Case Western Reserve Journal of International Law. 8(1). Case Western Reserve University. Cleveland

Meng Soon, C. (2016). Restrictions on Foreign Military Activities in the Exclusive Economic Zone: Major Powers' 'Lawfare'. Vol42 n.1. Journal of the Singapore Armed Forces

Maribus gGmbH. (2017). World Ocean Review. Hamburg

Nandan, S.N. (nd). The Exclusive Economic Zone: A Historical Perspective. FAO. Retrieved from http://www.fao.org/docrep/s5280T/ s5280t0p.htm\#TopOfPage

Neves Coelho, P. (2013). What is the Commission on the Limits of the Continental Shelf?. Institut Océanographique. Fondation Albert Ier, Prince de Monaco. Monaco

Oxman, B. H. (1996). The Rule of Law and the United Nations Convention on the Law of the Sea. Retrieved from www.ejil.org/ 
pdfs/7/3/1369.pdf

Patuzi, D. (2015). The Concept of the Economic Exclusive Zone. Academic Journal of Business, Administration, Law and Social Sciences. 1(1). IIPCCL Publishing. Tirana

Pedrozo, R. (2014). Military Activities in the Exclusive Economic Zone: East Asia Focus. International Law Studies. Vol.90. US Naval War College

Radio Sweden. (2015). Security Expert: Russia Seeks to Block Baltic Energy Independence. Retrieved from https://sverigesradio.se/ sida/artikel.aspx?programid $=2054 \&$ artikel $=6157186$

Ravin, M. (2005). ITLOS and Dispute Settlement Mechanisms of the United Nations Convention on the Law of the Sea. United Nations-The Nippon Foundation

Roach, A., Smith, R. (1994). Chapter VII. Exclusive Economic Zone. International Law Studies. Vol.66. US Naval War College. Newport

RWH Advisory Group. (2015). Russian Naval Vessels Target Ship Laying NordBalt Cable Designed to Ease Lithuanian Dependency on Russian Electric Power. Retrieved from https://www.rwradvisory.com/russian-naval-vessels-target-ship-laying-nordbalt-cabledesigned-to-ease-lithuanian-dependency-on-russian-electric-power/

Shlaim, A. (1996). The Middle East: The Origins of Arab-Israeli Wars. Ngaire Woods ed. Explaining International Relations since 1945. Oxford University Press. Oxford. Retrieved from http://users.ox.ac.uk/ ssfc0005/The\%20Middle $\% 20$ East $\% 20$ The $\% 20$ Origins $\% 20$ of $\% 20$ Arab-Israeli\%20Wars.html

Sun, Z. (2012). Conservation and Utilization of the Living Resources in the Exclusive Economic Zone-How Far Can We Go?. Proceedings from the 2012 LOSI-KIOST Conference on Securing the Ocean for the Next Generation. Seoul

Treves, T. (2015). The Legal Nature of Coastal States' Rights in the Maritime Areas Under UNCLOS. International Symposium on the Law of the Sea. The Role of the Sea in the Seas of Asia. Ministry of Foreign Affairs. Tokyo

Treves, T. (2017). 1958 Geneva Conventions on the Law of the Sea. United Nations Audiovisual Library of International Law. Retrieved from http://legal.un.org/avl/ha/gclos/gclos.html

United Nations. (1945). Charter of the United Nations and Statute of the International Court of Justice. San Francisco

United Nations. (1958). Convention on the Territorial Sea and the Contiguous Zone. Geneva

United Nations. (1982). United Nations Conventions on the Law of the Sea. Geneva

United Nations. (1998). The United Nations Convention on the Law of the Sea. A Historical Perspective. Retrieved from http://www. un.org/depts/los/convention_agreements/convention_historical_perspective.htm

United Nations. (2017). UN Charter Principles. Retrieved from https://www.un.org/ruleoflaw/thematic-areas/international-law-courtstribunals/un-charter-principles/

US Department of State. (2017). US Extended Continental Shelf Project. Retrieved from https://www.continentalshelf.gov/faq/index. htm

World Ocean Review. (2017). The law of the sea: A powerful instrument. Retrieved from http://worldoceanreview.com/en/wor-1/lawof-the-sea/ 
Tiziana MELCHIORRE, PhD, has worked as Fellow at NATO Energy Security Centre of Excellence (ENSEC COE). Previously, she worked as Consultant on energy issues and as Researcher at the Stockholm University and as Visiting Researcher at the Centre d'Eduted et de Recherches Internationales (CERI)-Sciences Po in Paris. She has also worked as trainee at the European Commission in Brussels and at the Council of the Baltic Sea States in Sweden. She holds a PhD in International Relations from the Stockholm University, and an Interdisciplinary Master in East European Research and Studies and a Bachelor in International Sciences and Diplomacy with a specialization in European Studies from the University of Bologna. She has several publications in international journals. Research interests: energy, geopolitics, international affairs, regional cooperation, hard security, Eastern and Northern Europe.

Tomas PLÉTA, is currently Communication and Information System Officer/Head of Support Division at NATO Energy Security Centre of Excellence (ENSEC COE). Before joining NATO ENSEC COE, he worked as IT Specialist first in the Lithuanian Army and later at the Lithuanian Ministry of Defense. He holds a Master's degree in Management and Business Administration and two bachelors in Informatics Engineering from the Vilnius Gediminas Technical University and in Informatics from the Panevėžys College respectively. He's an expert in cybersecurity on which he has published in international journals. Research interests: cybersecurity, cyberdefense, energy infrastructure protection, energy infrastructure protection management, cybersecurity management.

ORCID ID: https://orcid.org/0000-0002-5376-6873 